\title{
PENGARUH PEMBELAJARAN KONTEKSTUAL BERBANTUAN HANDS ON ACTIVITY TERHADAP KEMAMPUAN PEMECAHAN MASALAH MATEMATIK DAN RASA INGIN TAHU SISWA
}

\author{
Niken Dwi Listriani ${ }^{a}$, Khafidhoh Nurul Aini ${ }^{b}$ \\ ${ }^{a}$ JurusanPendidikan Matematika, Universitas Islam Darul 'Ulum Lamongan \\ Jl. Airlangga No.3 Sukodadi Lamongan, niken.listriani@gmail.com \\ ${ }^{\mathrm{b}}$ JurusanPendidikan Matematika, Universitas Islam Darul 'Ulum Lamongan \\ Jl. Airlangga No.3 Sukodadi Lamongan, khafidhohnurul@unisda.ac.id
}

\begin{abstract}
Abstrak
Penelitian ini bertujuan untuk mengetahui ada tidaknya pengaruh kemampuan pemecahan masalah matematik dan rasa ingin tahu siswa antara yang mengikuti pembelajaran Kontekstual Berbantuan Hands On Activity dan siswa yang mengikuti pembelajaran konvensional pada materi peluang di kelas VIII SMPN 1 Karanggeneng. Berdasarkan hasil penelitian menggunakan uji t terhadap kemampuan pemecahan masalah matematik, maka di peroleh $t_{\text {hitung }}=5,38$ untuk mengetahui nilai t tabel dengan derajat kebebasan $(\mathrm{dk})=62$ dengan taraf signifikansi 5\%, dari hasil perhitungan di dapat nilai $t_{\text {tabel }}=1,99$. Dengan membandingkan $t_{\text {hitung }}$ dan $t_{\text {tabel }}$, maka $t_{\text {hitung }}>t_{\text {tabel }}(5,38$ $>1,99$ ), ini berarti $H_{0}$ di tolak dan $H_{1}$ di terima, sedangkan sikap rasa ingin tahu siswa dapat dilihat dari perhitungan dengan menggunakan uji t-test maka diperoleh $t_{\text {hitung }}=2,57$ dengan $t_{\text {tabel }}$ derajat kebebasan 62 dengan taraf signifikansi $5 \%$ adalah 1,99 . Hasil perhitungan t dengan taraf signifikansi $5 \%$ dinyatakan signifikan bahwa $t_{\text {hitung }}>t_{\text {tabel }}>1,(2,60>1,99)$. Ini berarti $H_{0}$ ditolak dan $H_{1}$ di terima. Sehingga dapat disimpulkan bahwa pembelajaran Kontekstual Berbantuan Hands On Activity memberikan pengaruh yang signifikan terhadap kemampuan pemecahan masalah matematik dan rasa ingin tahu siswa.
\end{abstract}

Kata Kunci : Pembelajaran kontekstual berbantuan hands on activity, kemampuan pemecahan masalah matematik, rasa ingin tahu.

\begin{abstract}
The study aims to determine whether there is an influence On mathematical problem-solving skills and the curiosity of students among those following Hands-On Activity Contextual learning and students who follow conventional learning On the opportunity material in class VIII SMPN 1 Karanggeneng. Based on the results of the study using T-test on the ability to solve mathematical problems, then get $T \_$hitung $=5.38$ to know the value of $T$ table with the degree of freedom $(D K)=$ 62 with a significance level of 5\%, from the results of calculations, at can be valued $t_{-}$Table $=$ 1.99. By comparing the T_hitung and T_tabel, then T_hitung > T_tabel $(5.38>1.99)$, this means $H_{-} O$ in the decline and $H_{-} 1$ in the receive, while the attitude of curiosity students can be seen from the calculation by using a test T-Test then obtained $T_{-}$hitung $=2.57$ with $T_{-}$( The degree of Freedom 62 with a significance of 5\% equivalent to 1.99. The result of calculating $T$ with a level of significance of $5 \%$ is stated significantly that the T_hitung > T (table) $>1,(2.60>1.99)$. This means that $H_{-} O$ is rejected and $H_{-} 1$ received. It is concluded that Hands-On Activity contextual learning has a significant influence on the ability to solve mathematical problems and students ' curiosity.
\end{abstract}

Keywords: Contextual learning assisted Hands-On Activity, the ability to solve mathematical problems, curiosity.

\section{PENDAHULUAN}

Matematika sebagai salah satu mata pelajaran dasar pada setiap jenjang pendidikan formal, memiliki peranan yang sangat penting dalam pendidikan. Menurut Permendiknas No. 22 tujuan pembelajaran matematika disekolah adalah : (1) memahami konsep matematika, menjelaskan keterkaitan antar konsep dan mengaplikasikan konsep secara luwes, akurat, efisien dan tepat dalam pemecahan masalah, (2) 
menggunakan penalaran pada pola dan sifat, melakukan manipulasi metematika dalam membuat generalisasi, menyusun bukti atau menjelaskan gagasan pernyataan matematika, (3) memecahkan masalah yang meliputi kemampuan memahami masalah, merancang model matematika, menyelesaikan model dan menafsirkan model yang diperoleh, (4) mengkomunikasikan gagasan dengan simbol, tabel, diagram atau media lain untuk memperjelas keadaan atau masalah dan (5) memiliki sikap menghargai kegunaan matematika dalam kehidupan (Permendiknas, 2006:346).

Adapun tujuan pembelajaran matematika menurut kurikulum 2004 adalah sebagai berikut melatih cara berpikir dan bernalar menarik kesimpulan, mengembangkan pemikiran divergen orisinil, rasa ingin tahu membuat prediksi dan dugaan serta coba - coba, mengembangkan kemampuan pemecahan dan mengembangkan kemampuan menyampaikan informasi atau mengkomunikasikan gagasan, antara lain melalui pembicaraan lisan, catatan, grafik, peta dan diagram dalam menjelaskangagasan. Untuk mencapai tujuan pembelajaran matematika, salah satu kemampuan yang harus dikuasai siswa adalah kemampuan pemecahan masalah matematik.

Kemampuan pemecahan masalah matematik dapat dilihat dari proses belajar siswa dan hasil belajar siswa. Proses pemecahan masalah matematik merupakan salah satu kemampuan dasar matematik yang harus dikuasai siswa sekolah menengah. Pentingnya kepemilikan kemampuan tersebut tercermin dari pernyataan Branca (Hendriana, dkk., 2014: 23) bahwa pemecahan masalah merupakan salah satu tujuan penting dalam pembelajarandan pemecahan masalah matematik mempunyai dua makna yaitu sebagai pendekatan pembelajaran dan sebagai kegiatan atau proses dalam melakukan doing math. Pemecahan masalah matematik sebagai suatu proses meliputi beberapa kegiatan yaitu : mengidentifikasi kecukupan unsur untuk penyelesaian masalah, memilih dan melaksanakan strategi untuk menyelesaikan masalah, melaksanakan perhitungan dan menginterpretasi solusi terhadap masalah semula dan memeriksa kebenaran solusi. Menurut Polya, ada 4 (empat) langkah penting dalam yang harus dilakukan dalan memecahkan masalah, yaitu : (1) memahami masalah; (2) merencanakan pemecahan masalah; (3) melaksanakan pemecahan masalah yang telah direncanakan dan (4) memeriksa kembali hasil yang diperoleh (looking bock) (Arifin, 2009 : 113).

Selain kemampuan pemecahan masalah matematik, sikap rasa ingin tahu sangat penting bagi setiap siswa dalam proses pembelajaran karena mendorong terwujudnya kebermaknaan dalam belajar sehingga rasa ingin tahu merupakan jiwa dan hakikat budaya belajar. Rasa ingin tahu adalah sikap dan tindakan yang selalu berupaya untuk mengetahui lebih mendalam dan meluas dari sesuatu yang dipelajarinya, dilihat, dan didengar (Kemendiknas, 2010:10). Rasa ingin tahu membuat siswa lebih peka dalam mengamati berbagai fenomena atau kejadian di sekitarnya juga dapat digunakan untuk menunjukkanrasa ketertarikan akan sesuatu. Keingintahuan seorang siswa dapat dicirikan dengan seringnya bertanya dan mencari tahu tentang sesuatu yang sedang dihadapi. Adapun indikator rasa ingin tahu (Kemendiknas, 2010:34), yang meliputi : (1) siswa cenderung bertanya selama pembelajaran jika ada hal yang tidak dipahami, (2) membaca sumber diluar buku teks tentang materi yang terkait dengan materi pembelajaran, (3) membaca atau mendiskusikan gejala alam atau pembelajaran yang baru terjadi dan (4) bertanya tentang sesuatu yang terkait dengan materi pelajaran tetapi diluar yang dibahas dikelas. Dari pendapat diatas maka dapat disimpulkan bahwa 
indikator sikap rasa ingin tahu yaitu siswa akan lebih sering bertanya selama proses pembelajaran mencari sumber diluar buku dan mendiskusikan pembelajaran yang terjadi.

Salah satu model pembelajaran yang diduga dapat meningkatkan kemampuan pemecahan masalah matematik dan rasa ingin tahu adalah dengan model pembelajaran kontekstual berbantuan hands on activity. Model pembelajaran kontekstual (Kemendikbud, 2013) merupakan suatu proses pendidikan yang holistik dan bertujuan memotivasi siswa untuk dapat memahami dan mengaitkan materi yang dipelajari dengan kehidupan sehari - hari. Pendekatan kontekstual dapat diartikan sebagai pembelajaran yang menggunakan konsep-konsep dan hubungan-hubungan dari situasi-situasi atau masalah-masalah yang ditemukan dalam kehidupan sehari-hari (Novianti \& Shodikin, 2018). Tujuan utama dalam pembelajaran kontekstual adalah membantu para siswa dengan cara yang tepat untuk mengaitkan makna pada pelajaran akademik mereka. Pembelajaran kontekstual adalah konsep belajar yang membantu guru untuk mengaitkan antara materi yang diajarkannya dengan situasi dunia nyata siswa dan mendorong siswa membuat hubungan antara pengetahuan yang dimilikinya dengan penerapannya dalam kehidupan mereka sehari - hari.

Menurut Anggraeni (Gloria \& Lestari, 2012), hands on activity dapat membantu siswa dalam upaya peningkatan keterampilan proses, karena hands on activity merupakan stimulus bagi siswa untuk aktif selama proses pembelajaran. Dengan hands on activity siswa mendapatkan pengalaman dan penghayatan terhadap konsep - konsep dalam pembelajaran. Selain untuk membuktikan fakta dan konsep, hands on activity juga mendorong rasa ingin tahu siswa secara lebih mendalam sehingga cenderung untuk membangkitkan siswa mengadakan penelitian untuk mendapatkan pengamatan dan pengalaman dalam dalam proses ilmiah. Melalui hands on activity siswa juga dapat memperoleh manfaat antara lain : menambah minat, motivasi, menguatkan ingatan dapat mengatasi masalah kesulitan belajar, menghindarkan salah paham, mendapatkan umpan balik dari serta menghubungkan yang konkrit dan yang abstrak (Kartono, 2010: 24).

Berdasarkan uraian di atas pembelajaran kontekstual berbantuan hands on activity memberikan siswa pengalaman dan kemampuan belajar yang selalu terkait dengan permasalahan permasalahan aktual yang terjadi di lingkungannya. Dalam rangka mengoptimalkan pembelajaran dengan pendekatan kontekstual yang dapat mempengaruhi kemampuan pemecahan masalah matematik siswa, guru juga perlu memperhatikan sikap rasa ingin tahu siswa dalam penyelesaian permasalahan matematik. Melalui model pembelajaran kontekstual berbantuan Hands on Activity siswa diharapkan menjadi lebih aktif dalam pembelajaran, berani untuk bertanya dan lebih fokus terhadap apa yang diajarkan. Berdasarkan uraian diatas, maka penulis tertarik melakukan penelitian yang berjudul "Pengaruh pembelajaran Kontekstual berbantuan Hands On Activity Terhadap Kemampuan Pemecahan Masalah Matematik dan Rasa Ingin Tahu Siswa SMP Negeri 1 Karanggeneng". Berdasarkan latar belakang tersebut, dapat dirumuskan permasalahan sebagai berikut: (1) Bagaimana pengaruh pembelajaran kontekstual berbantuan hands on activity terhadap kemampuan pemecahan masalah matematik siswa SMP Negeri 1 Karanggeneng ? (2) Bagaimana pengaruh pembelajaran kontekstual berbantuan hands on activity terhadap rasa ingin tahu siswa SMP Negeri 1 Karanggeneng ? Berdasarkan rumusan masalah, maka tujuan yang ingin dicapai dari penelitian ini adalah (1) untuk mengetahui pengaruh pembelajaran kontekstual berbantuan 
hands on activity terhadap kemampuan pemecahan masalah matematik siswa SMP Negeri 1 Karanggeneng (2) untuk mengetahui pengaruh pembelajaran kontekstual berbantuan hands on activity terhadap rasa ingin tahu siswa SMP Negeri 1 Karanggeneng.

\section{METODE}

Penelitian ini menggunakan metode penelitian kuantitatif dapat diartikan sebagai metode penelitian yang dilandaskan pada filsafat positifisme, digunakan untuk meneliti pada populasi dan sampel tertentu, pengumpulan data menggunakan instrumen penelitian, analisis data bersifat kuantitatif atau statistik dengan tujuan untuk menguji hipotesis yang telah ditetapkan ini adalah penelitian kuantitatif. Metode penelitian yang digunakan dalam penelitian ini adalah metode quasy experiment atau eksperimen semu, yaitu desain ini memiliki kelompok kontrol tetapi tidak berfungsi sepenuhnya untuk mengontrol variabel - variabel luar yang mempengaruhi pelaksanaan eksperimen. Dalam hal ini subjek dikelompokkan menjadi dua kelompok. Kelompok pertama adalah kelompok eksperimen, yaitu siswa yang menggunakan model pembelajaran kontekstual berbantuan hands on activity. Kelompok kedua adalah kelompok kontrol, yaitu siswa yang menggunakan model pembelajaran konvensional. Desainnya dapat dilihat pada Tabel 1 .

Tabel 1. Desain Penelitian

\begin{tabular}{lccc}
\hline \multicolumn{1}{c}{ Group } & Pre-test & Perlakuan & Post-test \\
\hline Eksperimen & $A_{1}$ & $X_{1}$ & $A_{2}$ \\
\hline Kontrol & $B_{1}$ & $X_{2}$ & $B_{2}$
\end{tabular}

Keterangan:

$A_{1}=$ Pemberian tes awal (pre test) untuk model pembelajaran kontekstual berbantuan Hands On Activity

$A_{2}=$ Pemberian tes akhir (post test) untuk model pembelajaran kontekstual berbantuan Hands On Activity

$B_{1}=$ Pemberian tes awal (pre test) untuk model pembelajaran konvensional

$B_{2}=$ Pemberian tes akhir (post test) untuk model pembelajaran konvensional

$X_{1}=$ Perlakuan di kelas eksperimen berupa penggunaan model kontekstual berbantuan Hands On Activity

$X_{2}=$ Perlakuan di kelas kelompok menggunakan model pembelajaran konvensional berupa metode ceramah

Berdasarkan tabel di atas, sebelum diberi perlakuan kedua kelas tersebut (eksperimen dan kontrol) dilakukan tes awal (pretest). Fungsi pretest tersebut untuk mengukur sejauh mana kemampuan awal siswa terhadap materi yang akan diajarkan. Kemudian pada kegiatan pembelajaran, kelas eksperimen diberi perlakuan dengan model pembelajaran kontekstual berbantuan Hands On Activity dalam pembelajaran. Sedangkan pada kelas kontrol dengan menggunakan model konvensional yaitu berupa metode ceramah. Setelah diberi perlakuan pada kedua kelas sampel penelitian, kemudian dilakukan tes akhir post-test. Pemberian post-test digunakan untuk mendapatkan data hasil dari kemampuan kemampuan pemecahan masalah dan rasa ingin tahu siswa setelah diberi perlakuan pembelajaran kontekstual berbantuan hands on activity. Populasi dalam penelitian ini adalah seluruh siswa-siswi kelas VIII-A yang berjumlah 16 siswa laki-laki dan 16 siswi perempuan dari 32 siswa-siswi dan VIII-B yang berjumlah 18 siswa laki-laki dan 14 siswi perempuan dari 32 siswasiswi SMP N 1 Karanggeneng semester genap tahun ajaran 2018/2019. Untuk memudahkan pengambilan dan pengolahan data, penelitian mengambil dua kelas yaitu kelas VIII yang ada di SMP N 1 Karanggeneng sebagai sampel penelitian. Satu kelas sebagai kelas eksperimen yaitu kelas VIII-A dan satu kelas lainnya sebagai kelas kontrol yaitu kelas VIII-B. Diharapkan sampel yang 
terpilih merupakan sampel yang dapat mewakili dari keseluruhan populasi yang ada di SMP N 1 Karanggeneng.Teknik pengumpulan data yang digunakan adalah metode tes dan metode angket.

1. Analisis Kemampuan Pemecahan Masalah

Hipotesis yang telah dirumuskan akan dianalisis dengan menggunakan uji-t. Namun sebelum menggunakan uji - $\mathrm{t}$, terlebih dahulu dilakukan uji normalitas dan uji homogenitas. Untuk mengetahui pengaruh model pembelajaran kontekstual berbantuan Hands On Activity terhadap kemampuan pemecahan masalah matematik siswa dilakukan dengan uji hipotesis. Hipotesis statistik yang diuji dalam penelitian ini menggunakan Uji $\mathrm{t}$ adalah sebagai berikut :

$\mathrm{H}_{0}: \mu_{1} \leq \mu_{2}$

$H_{1}: \mu_{1}>\mu_{2}$

Keterangan :

$\mathrm{H}_{0}$ : Tidak ada pengaruh model pembelajaran kontekstual berbantuan Hands On Activity terhadap kemampuan pemecahan masalah matematik siswa SMP Negeri 1 Karanggeneng

$\mathrm{H}_{1}$ : Ada pengaruh model pembelajaran kontekstual berbantuan Hands On Activity terhadap kemampuan pemecahan masalah matematik siswa SMP Negeri 1 Karanggeneng

$\mu_{1}$ : rata - rata kemampuan pemecahan masalah siswa kelompok eksperimen

$\mu_{2}$ : rata - rata kemampuan pemecahan masalah siswa kelompok kontrol

Hipotesis statistik uji dengan menggunakan uji-t dengan taraf signifikan $\sigma=0,05$.

2. Analisis Angket Rasa Ingin Tahu

Skala rasa ingin tahu siswa dalam penelitian ini digunakan untuk mengetahui pengaruh model pembelajaran kontekstual berbantuan Hands On Activity terhadap rasa ingin tahu siswa SMP Negeri 1
Karanggeneng. Skala rasa ingin tahu ini menggunakan skala likert. Menurut Sudijono (2008:85) skala likert adalah skala yang digunakan untuk mengukur sikap peserta didik. Pengukuran angket menggunakan skala likert dengan kriteria jawaban selalu (SL), sering (SR), kadang - kadang (KD) dan tidak pernah (TP) dalam (sugiyono, 2016 : 93). Item angket terdiri dari item positif dan negatif untuk setiap pilihan jawaban diberi penilaian tersendiri dimana item yang positif penilaian yang diberi antara 4-1 sedang item negatif diberi nilai 1-4 bsebagaimana terlihat pada Tabel 2 berikut :

\begin{tabular}{|c|c|c|}
\hline \multirow[t]{2}{*}{ Kategori } & \multicolumn{2}{|c|}{ Skor per butir } \\
\hline & & - \\
\hline Selalu & 4 & 1 \\
\hline Sering & 3 & 2 \\
\hline Kadang kadang & 2 & 3 \\
\hline Tidak pernah & 1 & 4 \\
\hline
\end{tabular}

Hasil angket rasa ingin tahu siswa dianalisis dengan menggunakan rumus $\mathrm{t}$ - test sebagai teknik analisis data yang digunakan untuk menguji apakah hipotesis alternatif $\left(\mathrm{H}_{1}\right)$ penelitian "model pembelajaran kontekstual berbantuan Hands On Activity terhadap rasa ingin tahu siswa SMP Negeri 1 Karanggeneng" ini terbukti atau tidak, maka peneliti menggunakan rumus t-test yaitu

$$
t \text { test }=\frac{M d}{\sqrt{\frac{\sum X d^{2}}{N(N-1)}}}
$$

Arikunto ( 2002: 79)

Keterangan :

Md : mean dari deviasi (d) antara kelas kontrol dan kelas eksperimen

Xd : perbedaan deviasi dengan mean deviasi

$\sum \mathrm{Xd}^{2}$ : jumlah kuadrat deviasi

$\mathrm{N}$ : subjek pada sampel

$\mathrm{dk}$ : ditentukan dengan N-1 
HASIL PENELITIAN

1. Kemampuan Pemecahan Masalah Matematik

a. Perbandingan Kemampuan

Pemecahan Masalah Matematik Siswa Kelompok Eksperimen dan Kelompok Kontrol

Seperti yang sudah diuraikan sebelumnya dalam penelitian ini kemampuan pemecahan masalah matematik terdapat 4 indikator yang meliputi (1) memahami masalah atau mengidentifikasi fakta atau informasi yang diberikan, (2) memilih dan menerapkan srategi untuk menyelesaikan masalah matematika, (3) menyelesaikan masalah dengan benar dan matematis dan, (4) memeriksa / mengecek kembali. Ditinjau dari keempat indikator kemampuan pemecahan masalah tersebut, perbandingan skor presentase rata rata tahapan kemampuan pemecahan masalah matematik siswa pada kelompok eksperimen dan kelompok kontrol disajikan pada Tabel 3.

Tabel 3. Perbandingan Kemampuan Pemecahan Masalah Matematik Siswa Berdasarkan Indikator Pemecahan Masalah

\begin{tabular}{|c|c|c|c|}
\hline \multirow[b]{2}{*}{ NO } & \multirow[b]{2}{*}{ Indikator } & Eksperimen & Kontrol \\
\hline & & $\begin{array}{l}\text { Rata - rata Per } \\
\text { Indikator }(\%)\end{array}$ & $\begin{array}{l}\text { Rata - rata Per } \\
\text { Indikator }(\%)\end{array}$ \\
\hline 1 & $\begin{array}{l}\text { Memahami masalah atau mengidentifikasi } \\
\text { fakta atau informasi yang diberikan. }\end{array}$ & 54,69 & 50,78 \\
\hline 2 & $\begin{array}{l}\text { Memilih dan menerapkan srategi untuk } \\
\text { menyelesaikan masalah matematika }\end{array}$ & 81,05 & 78,13 \\
\hline 3 & $\begin{array}{l}\text { Menyelesaikan masalah dengan benar dan } \\
\text { sistematis }\end{array}$ & 86,91 & 80,08 \\
\hline 4 & Memeriksa / mengecek kembali & 52,73 & 48,83 \\
\hline
\end{tabular}

Dari Tabel 3 diperoleh bahwa pada kelas eksperimen maupun kelas kontrol nilai rata - rata per indikator tertinggi dicapai pada kategori menyelesaikan masalah dengan benar dan sistematis. Kelas eksperimen mendapat nilai sebesar 86,91 sedangkan kelas kontrol mendapat nilai sebesar 72,50. Sementara nilai indikator terendah antara kelas eksperimen dan kelas kontrol dicapai pada kategori memeriksa atau mengecek kembali kelas eksperimen mendapat nilai 52,73 sedangkan kelas kontrol mendapatkan nilai sebesar 48,89.

$$
\text { Secara visual nilai siswa }
$$
berdasarkan indikator kemampuan pemecahan masalah matematik siswa kelas eksperimen dan kelas kontrol disajikan pada Gambar 1

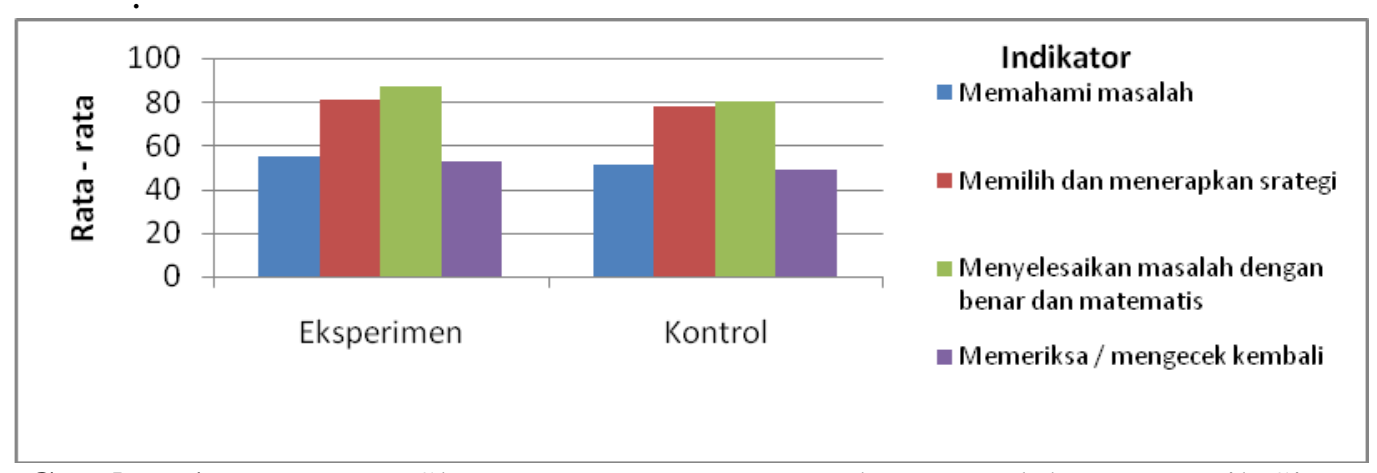

Gambar 1. Presentase Skor Kemampuan Pemecahan Masalah Matematik Siswa Kelas Eksperimen dan Kelas Kontrol 


\section{a. Pengujian Hipotesis}

Dari hasil perhitungan uji prasyarat menujukkan bahwa data kemampuan pemecahan masalah matematik siswa kelas eksperimen dan kelas kontrol berdistribusi normal dan homogen, selanjutnya dilakukan pengujian hipotesis. Pengujian hipotesis dilakukan pada data post test dengan menggunakan uji $\mathrm{t}$ analisis varians satu pihak. Setelah melakukan perhitungan dengan uji $t$ maka diperoleh menggunakan tabel distribusi t pada taraf signifikansi 5\% dengan $\mathrm{dk}=62$, $t_{\text {tabel }(0,05)}=1,99$. Hasil perhitungan $t_{\text {hitung }}=5,38$ dengan uji hipotesis disajikan pada Tabel 4.

Tabel 4. Hasil Uji Hipotesis

\begin{tabular}{cccc}
\hline Kelas & $\boldsymbol{t}_{\text {hitung }}$ & $\boldsymbol{t}_{\text {tabel }}$ & Kesimpulan \\
\hline Eksperimen & 5,83 & 1,99 & Ho Ditolak \\
\hline Kontrol & & & \\
\hline
\end{tabular}

Tabel 4 menunjukkan bahwa $t_{\text {hitung }}$ lebih besar dari $t_{\text {tabel }}(5,83>$ 1,99) maka dapat disimpulkan bahwa

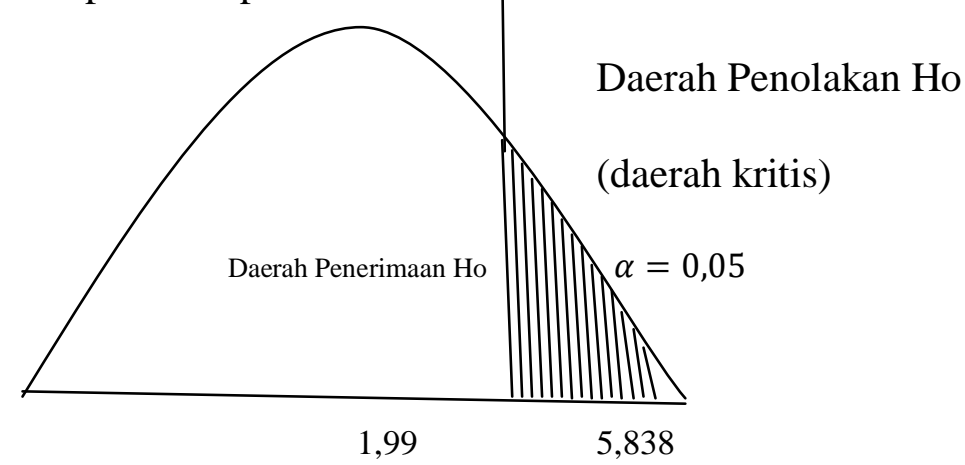
kurvanya.

Gambar 2. Kurva Hasil Uji Hipotesis

Berdasarkan Gambar 2 diketahui $\mathrm{t}=5,838$ dan merujuk pada $t_{\text {tabel }}$ dengan taraf signifikansi $95 \%$ dengan $\alpha=0,05$ dan df $\left(n_{1}+\right.$ $\left.n_{2}\right)-2$ diperoleh $t_{\text {tabel }}$ sebesar 1,99. Apabila dibandingkan $t_{\text {hitung }}$ dan $t_{\text {tabel }}$, maka $t_{\text {hitung }}>t_{\text {tabel }}$. Dengan demikian hipotesis nihil (Ho) ditolak dan hipotesis alternatif $\left(\mathrm{H}_{1}\right)$ diterima, sehingga dapat

2. Angket Rasa Ingin Tahu

a. Hasil Skor Angket Post Test Kelas Kontrol dan Kelas Eksperimen Berdasarkan
Ho ditolak dan $\mathrm{H}_{1}$ diterima dengan taraf signifikansi $5 \%$ berikut sketsa

disimpulkan bahwa rata - rata kemampuan pemecahan masalah matematik siswa yang diajarkan dengan model pembelajaran kontekstual berbantuan Hands On Activity lebih tinggi dari pada rata rata kemampuan pemecahan masalah matematik siswa yang diajarkan dengan model pembelajaran konvensional.

Hasil Skor angket rasa ingin tahu siswa dari hasil data Post Test kelompok eksperimen dan kelompok kontrol disajikan pada Gambar 3 berikut. 


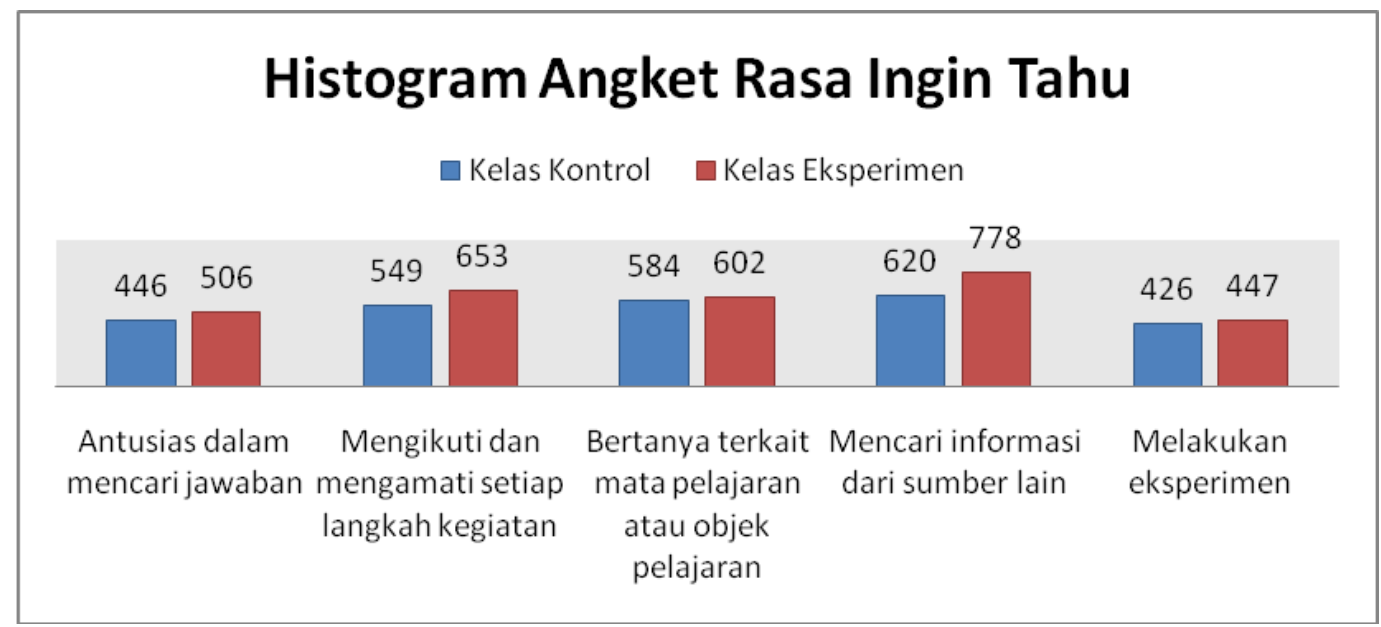

\section{Gambar 3. Histogram Angket Rasa Ingin Tahu Siswa Kelas Kontrol dan Kelas Eksperimen Berdasarkan Indikator}

Dari Gambar 3 terlihat perbedaan pada kelas eksperimen maupun kelas kontrol, dapat dijelaskan bahwa dari 32 siswa dari masing - masing kelompok, nilai yang diperoleh kelompok eksperimen lebih tinggi dibandingkan dengan kelompok kontrol.

\section{b. Pengujian Hipotesis}

Dari hasil perhitungan uji prasyarat menujukkan bahwa data kemampuan pemecahan masalah matematik siswa kelas eksperimen dan kelas kontrol, selanjutnya dilakukan pengujian hipotesis. Pengujian hipotesis dilakukan pada data post test dengan menggunakan uji t test. Dari hasil data angket dapat dilihat bahwa untuk menguji hipotesis alternatif $\left(\mathrm{H}_{1}\right)$ yang menyatakan terdapat pengaruh rasa ingin tahu siswa yang diajar dengan model pembelajaran kontekstual berbantuan Hands On Activity dan yang diajar dengan model konvensional. Pengujian hipotesis dilakukan pada data post test menggunkan teknik analisis uji $\mathrm{t}$ yang dimasukkan kedalam rumus berikut ini:

$$
\begin{aligned}
& \text { test }=\frac{M d}{\sqrt{\frac{\sum X^{2} d}{N(N-1)}}} \\
& =\frac{5,67}{\sqrt{\frac{19245}{64(64-1)}}} \\
& =\frac{5,67}{\sqrt{\frac{19245}{4032}}} \\
& =\frac{5,67}{\sqrt{4,77}} \\
& =\frac{5,67}{2,18} \\
& =2,60
\end{aligned}
$$

Dari analisis data skor angket rasa ingin tahu siswa terdapat perbedaan pada data post test kelas eksperimen dan kelas kontrol dengan diperoleh $t_{\text {hitung }}=2,57$ dengan $t_{\text {tabel }}$ derajat kebebasan $\mathrm{dk}=$ $\left(n_{1}+n_{2}-2\right)=(32+32-2)=$ 62 dengan taraf signifikansi $5 \%$ adalah 1,99. Hasil perhitungan t-skor dengan taraf signifikansi $5 \%$ dinyatakan signifikan bahwa $t_{\text {hitung }}>t_{\text {tabel }}(2,60>1,99)$. Dengan 
demikian $\mathrm{H}_{1}$ diterima yang berbunyi bahwa terdapat pengaruh antara ratarata rasa ingin tahu siswa yang diajar dengan model pembelajaran kontekstual berbantuan Hands On Activity dan yang diajar dengan model konvensional dan Ho ditolak.

\section{PEMBAHASAN}

\section{Kemampuan \\ Pemecahan \\ Masalah Matematik Siswa}

Berdasarkan hasil penelitian yang telah dilakukan, rumusan masalah pada penelitian ini dilakukan uji hipotesis data post test dengan menggunakan uji $t$. Pada uji $t$ diperoleh nilai $t_{\text {hitung }}=5,38$ sedangkan nilai $t_{\text {tabel }}=1,99$, kemudian nilai uji statistik hitung kemudian dibandingkan dengan nilai kritisnya. Dengan kriteria pengujiannya adalah Ho diterima jika $t_{\text {tabel }} \leq t_{\text {hitung }}$, dan Ho ditolak jika $t_{\text {hitung }}>t_{\text {tabel }}$, dengan $d k=\left(n_{1}+n_{2}-\right.$ 2). Dan diperoleh hasil $t_{\text {hitung }}>t_{\text {tabel }}$, yaitu 5,38 > 1,99 yang berada pada daerah penolakan Ho. Dengan demikian dapat disimpulkan bahwa Ho ditolak dan $\mathrm{H}_{1}$ diterima atau dengan kata lain rata - rata kemampuan pemecahan masalah masalah matematik pada kelompok eksperimen lebih tinggi dari rata rata kemampuan pemecahan masalah matematik siswa pada kelas kontrol.

Pada penilitian ini diketahui bahwa terdapat perbedaan rata - rata kemampuan pemecahan masalah matematik siswa pada kelas eksperimen dan kelas kontrol. Hal ini menunjukkan bahwa pembelajaran yang menggunakan model pembelajaran kontekstual berbantuan hands on activity memiliki rata - rata lebih tinggi dari pada pembelajaran menggunakan model pembelajaran konvensional. Dengan demikian hasil penelitian ini menunjukan bahwa penggunaan model pembelajaran kontekstual berbantuan hands on activity memberikan pengaruh yang signifikan terhadap kemampuan pemecahan masalah.

Hal ini sejalan dengan teori yang dikemukakan oleh Hatta dalam (Kartono, 2010) bahwa pembelajaran menggunakan strategi Hands On Activity mampu meningkatkan kemampuan berfikir siswa dalam menyelesaikan soal pemecahan masalah dan mampu menerapkan tidak hanya dari apa yang mereka pelajari, tetapi yang lebih penting adalah proses pembelajarannya yang dapat mereka gunakan dalam dalam situasi kehidupan nyata. Dalam journal education of technologies diungkapkan "Hands on activities was this reliance on object, tools and materials to teach mathematical and science". Pada model pembelajaran Hands on activity siswa dihadapkan pada objek, alat-alat dan materi yang lebih nyata sehingga memudahkan siswa memahami materi pelajaran dibandingkan dengan pembelajaran konvensional (Riyanti, 2009). Sesuai dengan hasil penelitian yang dilakukan oleh Zubaidah (2017) menyatakan bahwa kemampuan pemecahan masalah matematik dengan perlakuan model pembelajaran kontekstual berbantuan hands on activity lebih baik dibandingkan dengan siswa dengan perlakuan model pembelajaran kontekstual maupun model pembelajaran konvensional.

\section{Rasa Ingin Tahu Siswa}

Berdasarkan penelitian yang telah dilakukan, bahwa hasil analisis 
data post test skor angket rasa ingin tahu siswa terdapat perbedaan pada kelas eksperimen dan kelas kontrol dengan diperoleh $t_{\text {hitung }}=2,57$ dengan $t_{\text {tabel }}$ derajat kebebasannya $\mathrm{dk}=\left(n_{1}+n_{2}-2\right)=$ $(32+32-2)=62$ dengan taraf signifikansi $5 \%$ adalah 1,99. Hasil perhitungan t-skor dengan taraf signifikansi $5 \%$ dinyatakan signifikan bahwa $t_{\text {hitung }}>t_{\text {tabel }}$ $(2,60>1,99)$. Maka $\mathrm{H}_{1}$ diterima yang berbunyi bahwa terdapat perbedaan antara rata-rata rasa ingin tahu siswa yang diajar dengan model pembelajaran kontekstual berbantuan Hands On Activity dan yang diajar dengan model konvensional dan Ho ditolak. Dengan demikian hasil penilitian ini menujukkan bahwa penggunaan model pembelajaran kontekstual berbantuan hands on activity memberikan pengaruh yang signifikan terhadap rasa ingin tahu.

Hasil penelitian tersebut sesuai dengan pendapat Litman dan Spielberger (2005), bahwa rasa ingin tahu merupakan keinginan untuk mendapatkan pengetahuan yang baru dan pengalaman sensorik yang baru, yang memotivasi tindakan eksplorasi. Hasil penelitian tersebut juga sesuai dengan pendapat Hopkins dan Craig (dalam Raharja, dkk., 2018) menyatakan rasa ingin tahu adalah sesuatu yang dapat diaraih oleh para siswa jika kita membuatnya menjadi nyata dan fokus. Rasa ingin tahu dipresentasikan dengan kemampuan belajar dan semangat untuk melakukan penyelidikan yang kita ingin dimiliki oleh para siswa, hal tersebut menujukkan sikap rasa ingin tahu mereka. Temuan tersebut juga sesuai dengan hasil penelitian Aji
(2017) bahwa rasa ingin tahu yang dimiliki siswa dapat mempengaruhi prestasi belajar siswa. Rasa ingin tahu dapat memberikan dorongan kepada seseorang untuk mengetahui segala sesuatu yang membuat penasaran, hal ini dapat memancing keinginan seseorang tersebut untuk terus mencari tahu dan belajar baik secara langsung atau tidak langsung.

$$
\text { Penekanan pembelajaran }
$$

pada pendekatan kontekstual berbantuan hands on activity memberikan siswa pengalaman dan kemampuan belajar yang selalu terkait dengan permasalahan permasalahan aktual yang terjadi di lingkungannya. Temuan yang sama oleh Shodikin (2015), bahwa pembelajaran yang menekankan pada masalah kontesktual telah mampu membuat siswa terbiasa melakukan identifikasi terhadap masalah.

\section{KESIMPULAN DAN SARAN Kesimpulan}

Berdasarkan hasil analisis data pnelitian sebagaimana yang di sajikan dalam bab IV setelah dilaksanakannya penelitian, dapat di simpulkan bahwa : terdapat pengaruh yang signifikan penggunaan model pembelajaran kontekstual berbantuan hands on activity terhadap kemampuan pemecahan masalah. Hal ini dapat dilihat dari perhitungan dengan menggunakan uji t, dengan membandingkan $t_{\text {hitung }}$ dan $t_{\text {tabel }}$, maka $t_{\text {hitung }}>t_{\text {tabel }}(5,38>1,99)$, ini berarti $H_{0}$ ditolak dan $H_{1}$ diterima. Dengan demikian kemampuan pemecahan masalah matematik siswa yang diajar dengan model pembelajaran kontekstual berbantuan hands on activity lebih tinggi dari pada kemampuan pemecahan 
masalah matematik siswa yang diajar dengan model pembelajaran konvensional. Sedangkan terdapat pengaruh yang signifikan penggunaan model pembelajaran kontekstual berbantuan hands on activity terhadap sikap rasa ingin tahu. Hal dapat dilihat dari perhitungan dengan menggunakan uji $\mathrm{t}$ - test. Hasil perhitungan dengan taraf signifikansi $5 \%$ dinyatakan signifikan bahwa $t_{\text {hitung }}>t_{\text {tabel }}>$ $1,(2,60>1,99)$. Ini berarti Ho ditolak dan $H_{1}$ di terima.

\section{Saran}

Berdasarkan hasil hasil yang di peroleh dari penelitian, penulis menyarankan bagi sekolah dan pihak guru untuk dapat menerapkan model pembelajaran kontekstual berbantuan hands on activity untuk melatih keaktifan dan rasa ingin tahu siswa dalam proses pembelajaran, setelah mengetahui adanya pengaruh model pembelajaran kontekstual berbantuan hands on activity terhadap rasa ingin tahu siswa. Guru dapat memberikan materi yang menarik siswa dalam belajar, memberikan kesempatan untuk melakukan eksperimen dalam kegiatan pembelajaran, mengarahkan siswa agar selalu memperhatikan pembelajaran yang diberikan oleh bapak atau ibu guru.

\section{DAFTAR PUSTAKA}

Aji, H. W. (2017). Pengaruh Disiplin Belajar dan Rasa Ingin Tahu Terhadap Prestasi Belajar IPA Siswa Kelas V Sekolah Dasar Negeri Gugus 5 Kecamatan Pengasih Kabupaten Kulon Progo Yogyakarta. Skripsi. Program Studi Pendidikan Guru
Sekolah Dasar Jurusan Pendidikan Sekolah Dasar Fakultas Ilmu Pendidikan Universitas Negeri Yogyakarta.

Arifin, Z. (2009). Membangun Kompetensi Pedagogis Guru Matematika. Surabaya: Lentera Cendikia.

Arikunto, S. (2002). Dasar-Dasar Evaluasi Pendidikan. Jakarta: Bumi Aksara.

Hendriana, H. dan Soemarmo, U. (2014). Penilaian Pembelajaran Matematika. Bandung: Penerbit PT Refika Aditama.

Kemendikbud. (2013). Panduan Penguatan Proses Pembelajaran Sekolah Menengah Pertama. Jakarta: Kemendikbud.

Kemendiknas. (2010). Panduan Penerapan Pendidikan

KarakterBangsa. Jakarta:

Kementrian Pendidikan

Nasional.

Litman, J. A. \& Spielbeger, C. D. (2005). Measuring Epistemic Coriosity and Its Deversive and Specific Components. Journal of Personality Assesment, Vol.80(1), pp. 75-86.

Novianti, A. \& Shodikin, A. (2018). Pengembangan Bahan Ajar Kalkulus Diferensial Berbasis Animasi dengan Pendekatan Kontekstual dan Kearifan Lokal. de Fermat : Jurnal Pendidikan Matematika. Vol. 1(2), pp. 7278.

Permendiknas. (2006). Peraturan Menteri Pendidikan NasionalRepublikIndonesia

Nomor 22 Tahun 2006, tentang Standar Isi Untuk Satuan Pendidikan Dasar dan Menengah. 
Permendiknas. (2006). Peraturan Menteri Pendidikan

NasionalRepublikIndonesia

Nomor 22 Tahun 2006, tentang

Standar Isi Untuk Satuan

Pendidikan Dasar dan

Menengah.

Raharja, S., Wibhawa, M.R., Lukas, S. (2018). Mengukur Rasa Ingin

Tahu Siswa (Measuring Students' Curiosty). POLYGOT: a Journal of Languange, Literature, Culture, and Education. Vol. 14(2), pp. 151164.

Gloria, R.Y. \& Lestari, F.A. (2012). Penerapan Hands On Activity Untuk Meningkatkan Keterampilan Proses Sains Siswa Pasa Kompetensi Dasar Pencemaran Lingkungan di Kelas X Sman 1 Gegesik. Jurnal Scientiae Educatia, Vol. 1 (2), pp. 1-9

Riyanti. (2009). Pembelajaran Biologi Dengan Group Investigation Melalui Hands On Activities dan E - Learning Ditinjau dari Kreatifitas dan Gaya Belajar Siswa. Tesis. Program Pasca Sarjana Universitas Sebelas Maret: Surakarta.

Shodikin, A. (2015). Peningkatan Kemampuan Pemecahan Masalah Siswa melalui Strategi Abduktif-Deduktif pada Pembelajaran Matematika. Kreano: Jurnal Matematika Kreatif-Inovatif. Vol.6(2), pp.101-110.

Sudijono, A. (2008). Pengantar Evaluasi Pendidikan, Jakarta: Raja Grafindo Persada.

Sugiyono. (2016). Statistika untuk Penelitian.Bandung:

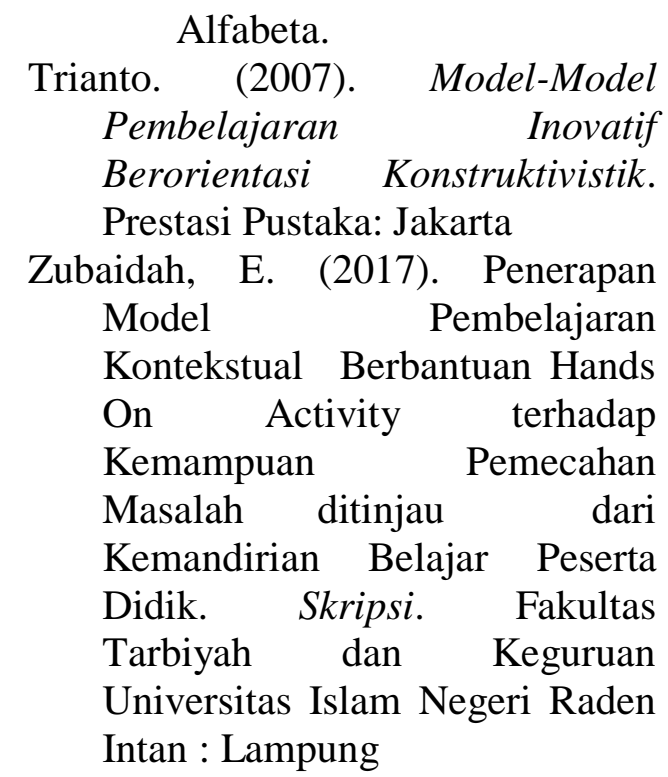

